\title{
RANDOMIZED CLINICAL TRIAL COMPARING SPINAL ANESTHESIA WITH LOCAL ANESTHESIA WITH SEDATION FOR LOOP COLOSTOMY CLOSURE
}

\author{
Rone Antônio Alves de ABREU', Filinto Anibal Alagia VAZ², Ricardo LAURINO³, \\ Manlio Basilio SPERANZINII ${ }^{2}$, Luís Cesar FERNANDES ${ }^{4}$ and Delcio MATOS ${ }^{4}$
}

\begin{abstract}
Context - Recent studies have shown that local anesthesia for loop colostomy closure is as safe as spinal anesthesia for this procedure. Objectives - Randomized clinical trial to compare the results from these two techniques. Methods - Fifty patients were randomized for loop colostomy closure using spinal anesthesia $(n=25)$ and using local anesthesia $(n=25)$. Preoperatively, the bowel was evaluated by means of colonoscopy, and bowel preparation was performed with $10 \%$ oral mannitol solution and physiological saline solution for lavage through the distal colostomy orifice. All patients were given prophylactic antibiotics (cefoxitin). Pain, analgesia, reestablishment of peristaltism or peristalsis, diet reintroduction, length of hospitalization and rehospitalization were analyzed postoperatively. Results - Surgery duration and local complications were greater in the spinal anesthesia group. Conversion to general anesthesia occurred only with spinal anesthesia. There was no difference in intraoperative pain between the groups, but postoperative pain, reestablishment of peristaltism or peristalsis, diet reintroduction and length of hospitalization were lower with local anesthesia. Conclusions - Local anesthesia plus sedation offers a safer and more effective method than spinal anesthesia for loop colostomy closure.
\end{abstract}

HEADINGS - Anesthesia, spinal. Anesthesia, local. Colostomy.

\section{INTRODUCTION}

Despite the apparently low risk in loop colostomy closure procedures, there have been reports of significant morbidity rates, of $22 \%$ to $30 \%{ }^{(10)}$ and $34 \%{ }^{(12)}$ with occasional mortality of $0 \%$ to $3 \%{ }^{(13)}$. Several anesthesia techniques have been utilized for this procedure, and general anesthesia and spinal block have been the ones most used.

A review of the literature showed that two studies have been conducted on loop colostomy closure using local anesthesia ${ }^{(1,2)}$. They showed that there were many advantages over general and spinal block anesthesia: it involves a limited area of the body; there is little interference with the physiology of other organs; there is no alteration in the patient's respiratory function; intraoperative hydration is achieved more simply; the immediate postoperative period is free of pain; and local anesthesia is well tolerated by high-risk patients.

Since studies carried out on loop colostomy closure under local anesthesia plus sedation have shown good results, a randomized clinical trial was proposed, with the aim of comparing the immediate results with spinal anesthesia (SA) and local anesthesia (LA) plus sedation for loop colostomy closure surgery.

\section{METHODS}

A randomized prospective clinical trial was conducted in accordance with the recommendations of the "Consort Statement"(8) (Figure 1), between June 2005 and June 2006. Patients from the General Surgery outpatient clinic of the Mandaqui Hospital Complex, São Paulo, SP, Brazil, were invited to participate in this investigation. Surgeons of our group performed the operations. The study was coordinated by the postgraduate course of the Discipline of Surgical Gastroenterology, Department of Surgery, Federal University of São Paulo, Escola Paulista de Medicina, São Paulo, SP, Brazil. This clinical trial was granted prior approval by the Research Ethics Committees of both institutions.

\footnotetext{
There were no conflicts of interest in the present research.

${ }^{1}$ Department of Surgery, Faculty of Medicine, Instituto Tocantinense Presidente Antonio Carlos -ITPAC - Araguaína, TO, Brazil; ${ }^{2}$ General Surgery and ${ }^{3}$ Anesthesiology Services, Mandaqui Hospital Complex, São Paulo, SP, Brazil; ${ }^{4}$ Discipline of Surgical Gastroenterology, Federal University of São Paulo, Escola Paulista de Medicina, São Paulo, SP, Brazil.

Correspondence: Dr. Rone A. A. Abreu - Rua Cel. Fleury, 1390 - Setor Carajás, 77800 - Araguaína, TO, Brasil. E-mail: roneabreu@uol.com.br
} 


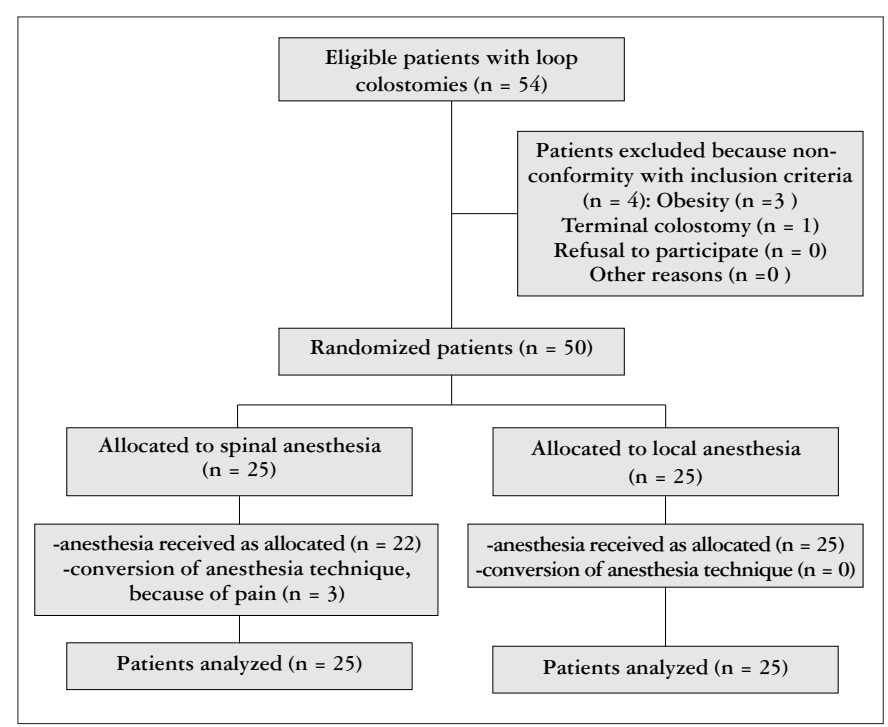

FIGURE 1. Trial profile and type of anesthesia

The following constituted exclusion criteria: age less than 16 years old; previous history of hypersensitivity, intolerance or allergic reactions to LA; presence of cognitive dysfunction, altered consciousness level or psychiatric disturbances; obesity (body mass index over $30 \mathrm{~kg} / \mathrm{m}^{2}$ ); presence of identified paracolostomic hernia, coagulopathy, use of anticoagulants and non-acceptance of the proposed method.

Each patient signed a free and informed consent statement. Fifty-four patients were initially considered eligible to participate in the investigation. However, after the initial clinical analysis, three patients were identified as obese (body mass index over $30 \mathrm{~kg} / \mathrm{m}^{2}$ ) and one had a terminal colostomy. Thus, 50 patients with loop colostomies were included in this study.

The patients were allocated using computer-generated random numbers. With the patient in the operating room, the anesthesiologist telephoned the randomization center, where the sealed envelopes containing the type of anesthesia that would be administered to each patient (SA or LA) were held. Furthermore, the "intention-to-treat" principle was applied in the present study. Twenty-five patients were allocated to SA and 25 patients to LA. The two groups were homogeneous with regard to demographic criteria and colostomy-related criteria (Table 1).

TABLE 1. Comparison of patient characteristics between the two groups analyzed.

\begin{tabular}{lccc}
\hline & $\begin{array}{c}\text { Spinal anesthesia } \\
\text { (SA) }\end{array}$ & $\begin{array}{c}\text { Local anesthesia } \\
\text { (LA) }\end{array}$ & $P$ \\
\hline Preoperative & & & \\
Age (years) & $35( \pm 16.2)$ & $35( \pm 13.6)$ & $0.712 \S$ \\
Sex ratio (M:F) & $22: 3$ & $23: 2$ & $0.882 \S$ \\
Body mass index $(\mathrm{kg} / \mathrm{m} 2)$ & $23.4( \pm 2.5)$ & $24( \pm 2.7)$ & $0.336 \S$ \\
ASA & & & $1.000 \S$ \\
$\quad$ I & 20 & 19 & \\
$\quad$ II & 5 & 6 & \\
Mean length of time with colostomy (months) & $12.5( \pm 9.8)$ & $13.8( \pm 14.6)$ & $0.613 \S$ \\
Colostomy & & & $0.863 \S$ \\
$\quad$ Transverse colon & 9 & 8 & \\
$\quad$ Sigmoid colon & 16 & 17 & \\
\hline
\end{tabular}

ASA $=$ American Society of Anesthesiology

$\S$ Mann-Whitney U test
All patients had the colon evaluated by means of colonoscopy. Following hospitalization, the preoperative procedures included oral mechanical preparation with $10 \%$ mannitol solution and intestinal lavage by physiological saline solution through the distal orifice of the colostomy. Antibiotic prophylaxis was administered and consisted of $2 \mathrm{~g}$ of intravenous cefoxitin, given 1 hour before surgery, and maintenance doses of $1 \mathrm{~g}$ given every 8 hours for 2 days. All operations, whether with LA or SA were monitored by the anesthetist. SA followed the technique standardized by the Brazilian Society of Anesthesiology. Sedation with intravenous midazolam $(0.03 \mathrm{mg} / \mathrm{kg})$ was given 10 minutes before the procedure. LA consisted of $2 \%$ lidocaine and $0.5 \%$ bupivacaine, at maximum doses of $7 \mathrm{mg} / \mathrm{kg}$ and $2.5 \mathrm{mg} / \mathrm{kg}$, respectively, diluted in $40 \mathrm{~mL}$ of distilled water. For each intervention, local infiltration of the anesthetic solution around the colostomy was performed by means of puncture using a $30 \times 7 \mathrm{~mm}$ needle. Complementary doses of anesthetic solution were administered in the subcutaneous tissue and aponeurosis and repeated according to each individual's need and sensitivity to pain.

The surgical technique was standardized for colostomy closure. It consisted of freeing the colon loop from the abdominal wall, excision of the skin and fibrous ring from around the colon, closure of the colon wall in a single seromuscular layer with polyglactin 910 thread $\left(\operatorname{Vycril}^{\circledR}\right)$, reintroduction of the colon into the abdominal cavity after colon reconstruction and synthesis of the abdominal wall in layers. Tenoxicam $20 \mathrm{mg}$ (IV) every 12 hours and dipyrone $1 \mathrm{~g}$ (IV) every 6 hours were prescribed for the postoperative period.

The principal objective of the study was to compare the immediate results between SA and LA for reconstructing the passage in loop colostomies. The hypothesis of the study was that LA plus sedation would produce less postoperative pain than would SA.

Intraoperative and postoperative variables were analyzed. The intraoperative variables consisted of: length of anesthesia, quantity of anesthetic utilized, pain, need for opioids, anesthesia conversion, length of the surgical procedure, local and systemic complications. Verbal complaints and facial expressions of pain, alterations in arterial pressure, cardiac and respiratory rates, level of oxygen saturation and agitation would lead to conversion of the anesthetic technique.

The postoperative variables were: pain assessment every hour for the first postoperative 6 hours, in the first postoperative day and at hospital discharge. Pain assessments were made by a blinded investigator using a visual analog scale graduation from 0 (absence of pain) to 10 (unbearable pain). Score 0 and 1: no pain. Score 2 and 3: slight pain. Score 4, 5, 6 and 7: moderate pain. Score 8, 9 and 10: severe pain. The need for opioids for pain control, reestablishment of intestinal function, diet reintroduction, local and systemic complications, length of hospitalization and need for rehospitalization were evaluated. 


\section{Statistical analysis}

Taking a significance level of $5 \%(\alpha=0.05)$ and a statistical power of $80 \%(\beta=0.20), 25$ patients would be necessary for each group, in order to detect a $70 \%$ difference in the mean pain values obtained from the visual analog scale, starting from the first hour of the postoperative period.

The hypothesis of obtaining a 70\% difference in the mean pain value in the postoperative period was based on the clinical survey of Nordin et al.(9), which analyzed patients with inguinal hernia who underwent surgical treatment under LA, regional block and general anesthesia.

The independent variables were compared using the Mann-Whitney test and Student's $t$ test. The proportions were compared using Fisher's exact test. The Friedman test was used to assess the evolution of the pain, complemented by multiple comparisons test.

\section{RESULTS}

While observing the "intervention-to-treat" principle, 25 patients were analyzed in the group that received SA and 25 in the group that received LA plus sedation. The intraoperative and postoperative results are in Tables 2 and 3, respectively. The mean duration of anesthesia (SA: 7.04 minutes, LA: 4.72 minutes, $P=0.001$ ) and the mean duration of the operation (SA: 122 minutes, LA: 104 minutes, $P=0.034$ ) were longer in the group under spinal anesthesia. The quantity of lidocaine infiltrated ranged from 300 to $600 \mathrm{mg}$ and the quantity of bupivacaine ranged from 50 to $100 \mathrm{mg}$.

TABLE 2. Intraoperative results for patients in both groups.

\begin{tabular}{lccc}
\hline & Spinal anesthesia & Local anesthesia & $\boldsymbol{P}$ \\
\hline Intraoperative variables & & & \\
Anesthesia duration (min) & $7.04( \pm 1.72)$ & $4.72( \pm 1.14)$ & 0.001 म \\
Procedure duration (min.) & $122( \pm 32.3)$ & $104( \pm 23.1)$ & $0.034 \S$ \\
Local complications & 3 & 0 & 0.234 ๆ \\
Systemic complications & 4 & 2 & $0,667 \boldsymbol{\Phi}$ \\
Anesthesia conversion & 3 & 0 & 0.234 ๆ \\
Intraoperative pain & $1.6( \pm 1.6)$ & $1.5( \pm 2.0)$ & $0.439 \S$ \\
\hline
\end{tabular}

$\$$ Mann-Whitney U test; 9 Fisher's exact test; $;$ Student test

TABLE 3. Postoperative results for patients in both groups.

\begin{tabular}{|c|c|c|c|}
\hline & $\begin{array}{c}\text { Spinal anesthesia } \\
\text { (SA) }\end{array}$ & $\begin{array}{l}\text { Local anesthesia } \\
\text { (LA) }\end{array}$ & $P$ \\
\hline \multicolumn{4}{|l|}{ Postoperative variables } \\
\hline Pain: 1st hour & $3.6( \pm 3.2)$ & $2.0( \pm 2.1)$ & $0.058 \S$ \\
\hline 2nd hour & $3.6( \pm 2.6)$ & $2.1( \pm 2.1)$ & $0.045 \S$ \\
\hline 3rd hour & $3.8( \pm 2.5)$ & $2.0( \pm 2.0)$ & $0.017 \S$ \\
\hline 4th hour & $3.6( \pm 2.4)$ & $1.8( \pm 2.1)$ & $0.007 \S$ \\
\hline 5th hour & $3.2( \pm 2.0)$ & $1.7( \pm 2.4)$ & $0.005 \S$ \\
\hline 6th hour & $3.2( \pm 2.2)$ & $1.4( \pm 1.7)$ & $0.003 \S$ \\
\hline 1 st postoperative day & $3.0( \pm 2.7)$ & $1.0( \pm 1.4)$ & $0.002 \S$ \\
\hline Hospital discharge & $0.6( \pm 0.8)$ & $0.2( \pm 0.6)$ & $0.028 \S$ \\
\hline Postoperative use of opioids & 5 & 2 & 0.2099 \\
\hline \multicolumn{4}{|l|}{ Return of intestinal peristaltism: } \\
\hline Water-air noises (hours) & $10( \pm 6.5)$ & $3( \pm 3.9)$ & $0.001 \S$ \\
\hline Gases (hours) & $19( \pm 10.2)$ & $14( \pm 9.4)$ & $0.101 \S$ \\
\hline Feces (days) & $2.7( \pm 0.6)$ & $1.7( \pm 1.1)$ & $0.001 \S$ \\
\hline Diet reintroduction (days) & $1.6( \pm 0.6)$ & $1.2( \pm 0.5)$ & $0.029 \S$ \\
\hline Systemic complications & 7 & 2 & 0.2099 \\
\hline Need for rehospitalization & 4 & 1 & $0.174 \uparrow$ \\
\hline Postoperative stay in hospital (days) & $3.8( \pm 3.7)$ & $2.6( \pm 1.2)$ & $0.001 \S$ \\
\hline $\begin{array}{l}\text { Stay in hospital including cases of } \\
\text { rehospitalization (days) }\end{array}$ & $4.5( \pm 4.0)$ & $2.8( \pm 1.9)$ & $0.001 \S$ \\
\hline
\end{tabular}

§ Mann-Whitney U test; Fisher's exact test
With regard to local complications, there was local pain and synthesis difficulty in three patients (3/25) in the SA group, while there were no cases in the group under LA plus sedation $(P=$ $0.234)$. Systemic complications occurred in four patients $(4 / 25)$ under SA: nausea (2), vomiting (1) and psychomotor agitation (1). Under LA, such complications occurred in two patients $(2 / 25)$, nausea (1) and psychomotor agitation (1) $(P=0.667)$.

There were no cases of anesthesia conversion in the group under LA plus sedation. However, in the group under SA there were three cases (3/25) of conversion: one patient to LA and two patients to general anesthesia $(P=0.234)$.

The evaluation of intraoperative pain did not show any difference between the groups. However, during the postoperative period, the mean values for pain reported by the patients were lower in the LA group $(P<0.05)$ from the second hour onwards. It was necessary to administer opioids during the postoperative period, to five patients $(5 / 25)$ in the SA group and two patients $(2 / 25)$ in the LA group $(P=0.417)$.

Reestablishment of intestinal peristaltism was faster in the LA group, as measured by the appearance of water-air noises (SA: $10 \mathrm{~h}$ vs LA: $3 \mathrm{~h} ; P=0.001$ ), elimination of flatus (SA: $19 \mathrm{~h}$ vs LA $14 \mathrm{~h} ; P=0.101$ ), elimination of feces (SA: 2.7 days vs LA: 1.7 days; $P=0.001$ ).

Diet reintroduction occurred earlier in the LA group (SA: 1.6 days vs LA: 1.2 days; $P=0.029$ ).

Postoperative systemic complications occurred in seven patients (7/25) in the SA group. There were three cases of post-puncture headache, two cases of prolonged ileus, one case of urine retention and one case of anastomosis dehiscence that led to reoperation. Two patients of the LA group $(2 / 25)$ had prolonged ileus that resolved with clinical treatment $(P=0.138)$.

There were four cases of rehospitalization $(4 / 25)$ in the SA group for prolonged ileus (two) and for post-puncture headaches (two). Only one case of prolonged ileus occurred in the other group. There was no statistical difference between the groups $(P=0.349)$.

The mean length of stay in hospital was 3.8 days in the SA group and 2.6 days in the LA group $(P=0.001)$.

There was no mortality.

\section{DISCUSSION}

Patients who were under 16 years old were excluded from this study. Nevertheless, the sample in this study had a relatively low mean age, and this may correlate with the high proportion of cases originating from trauma, i.e. victims of urban violence. The Mann-Whitney test found that the characteristics of two groups analyzed were homogeneous (Table 1), thus demonstrating the efficiency of the randomization. The stomas were closed late, after 12.5 to 13 months on average, because some patients had been operated in other hospitals. Regarding the segment of the colon that was brought to the exterior, the sigmoid predominated over the transverse colon, in both groups. This was probably because of the high proportion of cases that originated from trauma in the rectal-sigmoid segment, as victims of urban violence. 
The shorter duration of the operation in the group under LA may be explained by the partial separation between the subcutaneous tissue and the aponeurosis of the colon wall that is caused by the initial infiltration of anesthetic (around $50 \mathrm{~mL}$ ). This makes it easier to perform tissue dissection and release the colostomy, thereby shortening the operation time. This effect, together with delicate surgical maneuvers and meticulous manipulation of the parietal peritoneum made it possible to perform sutures without causing discomfort for the patients, as shown in Table 2. Interventions taking more than 120 minutes have been found to be a factor that increases the morbidity of the operation ${ }^{(17)}$.

In the group under LA, the same anesthesia solution as described by Abreu et al. ${ }^{(1)}$ was utilized, without the need to administer larger doses. Cantele et al..$^{(2)}$ used $1 \%$ lidocaine for loop colostomy closure under LA, while Haagmans et al..$^{(5)}$ used lidocaine and prilocaine for loop ileostomy closure. In both studies and in the present investigation, there were no detectable complications, and this proves the practicability of LA for performing loop colostomy closure surgery in such patients.

Three patients in the SA group presented state of pain that led to a decision to convert the anesthetic technique. However, there was no conversion to another technique in the group with LA. The difference was not statistically significant.

Four patients in the group under SA presented systemic complications during the operation: nausea (two), vomiting (one) and psychomotor agitation (one). Systemic complications also occurred in two patients in the other group: nausea (one) and psychomotor agitation (one), which may have been a collateral effect from midazolam ${ }^{(1)}$, but there was no statistical difference between the groups.

Visual analog scales are the method most recommended for measuring pain among adults, because they are simple, rapid and objective ${ }^{(15)}$. The first pain assessment was made in the surgical room, with low scores in both groups, thus showing the effectiveness and equivalence of the anesthetic methods under comparison. After the operation, the mean pain level was lower in the LA group during the first 6 hours, and there was a significant difference from the second hour onwards. According to Roberge and McEwen ${ }^{(11)}$, postoperative pain is also associated with the choice of local anesthetics. This conclusion came from a study in which they found that bupivacaine was important for obtaining low pain values.

There was a need for postoperative analgesic supplementation using an opioid (tramadol hydrochloride) for five patients $(5 / 25)$ in the spinal anesthesia group and for two patients $(2 / 25)$ in the other group, and this did not present any significant difference between the groups. Abreu et al. ${ }^{(1)}$ did not need to use opioids postoperatively in their series, but Haagmans et al. ${ }^{(5)}$ used opioids in two patients.

Reestablishment of intestinal peristaltism was faster in the LA group, as measured by the return of water-air noises, elimination of gases and feces. Williams et al. ${ }^{(16)}$ reported that gas elimination started after a mean of 2.3 days and feces elimination after 3.6 days (range: 1-7 days) among patients who underwent this procedure under general anesthesia. Diet reintroduction was also faster in the LA group. Souza et al..$^{(14)}$ used general anesthesia and achieved diet reintroduction among their patients between the 1st and $3 \mathrm{rd}$ postoperative days.

Postoperative complications occurred in seven patients (7/25) in the SA group: post-puncture headache (three), prolonged ileus (two), urine retention (one) and dehiscence of the anastomosis (one), which necessitated reoperation. In turn, there were two patients with complications in the LA group $(2 / 25)$, both with prolonged ileus that were treated clinically. There was no statistical difference between the groups in this respect. Complications such headache ${ }^{(4)}$ and bladder function disorders ${ }^{(6)}$ have been described in relation to SA, but no such complications have been reported with LA. Complications relating to colon reconstruction, such as prolonged ileus and dehiscence of anastomosis have been described in other studies ${ }^{(2)}$. There was no mortality in the present series, although this event has been reported by some investigations $^{(13)}$.

There were four cases of rehospitalization (4/25) in the SA group: prolonged ileus (two) and post-puncture headache (two); there was one case (1/25) in the other group, consisting of prolonged ileus but no significant difference was shown. The mean length of stay in hospital was greater (3.8 days) in the SA group than in the LA group (2.6 days). Including rehospitalization, the overall length of stay in hospital went up to 4.5 days for the spinal anesthesia group and 2.8 days for the other group. Cantele et al. ${ }^{(2)}$ reported a mean stay in hospital after the operation of 9 days, while for Abreu et al. ${ }^{(1)}$ it was 4 days. Studies in the literature using other anesthetic techniques have shown longer postoperative stay in hospital, of around 7 days $^{(3,7)}$.

It is possible that the result found in the present study would also be applicable to other samples and populations. It would, however, be important to conduct other randomized clinical trials covering different ethnic groups, other different healthcare provision models and, especially, older age groups that could present not only greater anesthesia risk but also greater number of comorbidities. Within the present context, and from the existing medical studies, LA plus sedation for loop colostomy closure is feasible, safe, less invasive and probably less expensive, which are important factors in present-day medicine.

\section{CONCLUSION}

LA plus sedation is more effective than SA for loop colostomy closure. 
Abreu RAA, Vaz FAA, Laurino R, Speranzini MB, Fernandes LC, Matos D. Ensaio clínico randomizado comparando raquianestesia com anestesia local, associadas à sedação para o fechamento de colostomia em alça. Arq Gastroenterol. 2010;47(3):270-4.

RESUMO - Contexto - Estudos recentes têm demonstrado que a anestesia local para o fechamento de colostomia em alça é tão segura quanto a raquianestesia para estes procedimentos. Objetivos - Comparar os resultados do fechamento de colostomia em alça usando essas duas técnicas. Métodos - Cinquenta pacientes foram randomizados para o fechamento de colostomia em alça sob raquianestesia $(n=25)$ e anestesia local $(n=$ 25). No pré-operatório, o cólon foi avaliado por colonoscopia e o preparo intestinal foi realizado com solução oral de manitol a $10 \%$ e limpeza com solução salina fisiológica através do orifício distal da colostomia. Todos os pacientes receberam antibioticoprofilaxia com cefoxitina. Dor, analgesia, restabelecimento do peristaltismo, reintrodução da dieta, tempo de internação e de reinternação foram analisados no pós-operatório. Resultados Duração da cirurgia e complicações locais foram maiores no grupo da raquianestesia. A conversão para anestesia geral ocorreu somente no grupo da raquianestesia. Em relação á dor intraoperatória, não houve diferença entre os grupos, mas a dor pós-operatória, restabelecimento do peristaltismo, reintrodução da dieta e tempo de hospitalização foram menores no grupo com anestesia local. Conclusão - A anestesia local associada à sedação ofereceu um método mais seguro e efetivo que a raquianestesia para o fechamento de colostomia em alça.

DESCRITORES - Raquianestesia. Anestesia local. Colostomia.

\section{REFERENCES}

1. Abreu RA, Speranzini MB, Fernandes LC, Matos D. Feasibility analysis of loop colostomy closure in patients under local anesthesia. Acta Cir Bras. 2006;21:275-8.

2. Cantele H, Méndez A, Leyba J. Colostomy closure using local anesthesia. Surg Today. 2001:31:678-80.

3. Edwards DP, Leppington-Clarke A, Sexton R, Heald RJ, Moran BJ. Stoma-related complications are more frequent after transverse colostomy than loop ileostomy: a prospective randomized clinical trial. Br J Surg. 2001;88:360-3.

4. Ganem EM, Castiglia YM, Vianna PT. Complicações neurológicas determinadas pela anestesia subaracnóidea. Rev Bras Anestesiol. 2002;52:471-80.

5. Haagmans MJ, Brinkert W, Bleichrodt RP, van Goor H, Bremers AJ. Short-term outcome of loop ileostomy closure under local anesthesia: results of a feasibility study. Dis Colon Rectum. 2004:47:1930-3.

6. Imbelloni LE, Beato L, Beato C, Cordeiro JA, Souza DD. Analgesia pós-operatória com bloqueio bilateral do nervo pudendo com bupivacaína S75:R25 a $0,25 \%$. Estudo piloto em hemorroidectomia sob regime ambulatorial. Rev Bras Anestesiol. 2005;55:614-21.

7. Law WL, Chu KW, Choi HK. Randomized clinical trial comparing loop ileostomy and loop transverse colostomy for faecal diversion following total mesorectal excision. Br J Surg. 2002;89:704-8.

8. Moher D, Schulz KF, Altman D. The CONSORT statement: revised recommendations for improving the quality of reports of parallel-group randomized trials. JAMA. 2001;285:1987-91.
9. Nordin P, Hernell H, Unosson M, Gunnarsson U, Nilsson E. Type of anaesthesia and patient acceptance in groin hernia repair: a multicentre randomised trial Hernia. 2004;8:220-5.

11. Roberge CW, McEwen M. The effects of local anesthetics on postoperative pain AORN J. 1998;68:1003-12.

12. Rullier E, Le Toux N, Laurent C, Garrelon JL, Parneix M, Saric J. Loop ileostomy versus loop colostomy for defunctioning low anastomoses during rectal cancer surgery. World J Surg. 2001;25:274-8.

13. Shellito PC. Complications of abdominal stoma surgery. Dis Colon Rectum. 1998;41:1562-72

14. Souza HFS, Sobral HAC, Taglietti EM, Monteiro EP, Gama MRVS, Formiga GJS. É necessário o Estudo do Cólon no Fechamento de Colostomias? Rev Bras Coloproctol. 2006;26:118-22.

15. Teixeira MJ, Pimenta CAM. Avaliação do doente com dor. In: Teixeira MJ, Figueiró JAB, editores. Dor: epidemiologia, fisiopatologia, avaliação, síndromes dolorosas e tratamento. São Paulo: Moreira Júnior; 2001. p.58-68.

16. Williams NS, Nasmyth DG, Jones D, Smith AH. De-functioning stomas: a prospective controlled trial comparing loop ileostomy with loop transverse colostomy. Br J Surg. 1986;73:566-70.

17. Wong RW, Rappaport WD, Witzke DB, Putnam CW, Hunter GC Factors influencing the safety of colostomy closure in the elderly. J Surg Res. 1994;57:289-92.

Received 20/10/2009. Accepted 26/2/2010 